\title{
Analysis of Strength Hydraulic Concrete Produced with a Mixture of Crushed Gneiss and Alluvial Sand
}

Mambou Ngueyep Luc Leroy ${ }^{1,2 *}$, Tchapga Gniamsi Guy Molay ${ }^{1}$, Ndop Joseph ${ }^{1,3}$ and NDJAKA Jean Marie bienvenu ${ }^{1}$

${ }^{1}$ Laboratory of Material Sciences, Department of Physics, Faculty of Sciences, University of Yaoundé 1, P.O. Box 812 Yaoundé, Cameroon

${ }^{2}$ School of Geology and Mining Engineering, University of Ngaoundéré, P.O. Box 115 Meiganga, Cameroon

${ }^{3}$ Douala Institute of Technology, P.O. Box 1623 Douala, Cameroon

\begin{abstract}
In recent years, the construction industry has been faced with a decline in the availability of natural sand due to the growth of the industry. In the present study, effect of gneiss powder as fine aggregate replacement on the compressive strength of concrete was investigated. The percentage of gniess powder added by weight was $0 \%, 25 \%, 50 \%, 75 \%$ and $100 \%$ as a replacement of river sand used in normal concrete. Tests were performed for compressive strength tests for all replacement levels of gneiss sand at different curing period ( 7 days, 28 days and 90 days). The results revealed that all the concrete made with different replacement present the good mechanical performance. At 90 days, the maximal values of compressive strength are obtained for conventional concrete $\mathrm{CN}$ (37.07 MPa), followed by CG75 concrete made with $25 \%$ of river sand and $75 \%$ of crushed gneiss (35.09 MPa). Then it is suggested that sand with a partial substitution of $75 \%$ can be effectively used in concrete production without affecting the strength and durability properties of the concrete.
\end{abstract}

Keywords: Alluvial sand; Concrete

\section{Introduction}

Concrete is one of the necessary elements for structural work the modern construction. It can be visualized as a multi-phase composite material made up of three phases; namely the mortar, mortar/aggregate interface, and the coarse aggregate phase [1]. Fine aggregate is used to ensure the continuity between the cement and gravel for the better cohesion of concrete [2]. River sand has been the most popularly used as fine in of concrete [3]. Developing countries, has taken a major initiative on developing the infrastructures such as express highways, power projects and industrial structures etc. So, there are great demands within the construction industries for river sand as fine aggregate used in the production of concrete. This has created a very difficult situation; the high cost of river and also a great fear from environmentalist and ecologist that in the future there may be scarcity of river sand, thus destroying the ecosystem [4]. Hence, researchers and practitioners have need to find materials which are affordable and available to partially or totally replaced river sand in the production of concrete $[5,6]$.

Felix Kala in 2013 [7] presented the result of an experimental investigation carried out to evaluate the strength properties of concrete mixture in which natural Sand was partially replaced with used granite Powder and cement was replaced with $7.5 \%$ silica fume, $10 \%$ fly ash, $10 \%$ slag and the dosage of superplasticiser added $1 \%$ by weight of cement. Fine aggregate was replaced with five percentages $(0 \%, 25 \%, 50 \%, 75 \%$ and $100 \%$ ) of Granite powder by weight. Compressive strength was determined at $1,3,7,14,28,56$ and 90 days. Splitting- tensile strength was determined at 1, 28, and 90 days. Flexural strength was determined at 1, 28 and 90 days. Modulus of elasticity was determined at 7, and 28 days. Water absorption test was determined at 1 , and 2 hours. Test results show that a marginal quantity of granite as partial sand replacement has beneficial effect on the above properties.

Kayathri in 2014 [8] carried out an experimental investigation to evaluate the possibility of using copper slag, fly ash and granite Powder as partial replacement in fine aggregate. Fine aggregate (Sand) was replaced with four different percentages $(0 \%, 25 \%, 50 \%$ and $75 \%)$ of fly ash, copper slag and granite Powder by weight. Compressive strength, split ensile strength were determined at 7, 14 and 28 days.
Test results indicate significant improvement in the strength properties of plain concrete by the inclusion of above mentioned industrial waste be effectively used in structural concrete.

Shehdeh et al. in 2016 [9] studied the possibility of using granite and iron powder as a partial replacement of sand in concrete. Regular sand was replaced with four percentages $(5 \%, 10 \%, 15 \%$ and $20 \%)$ of the granite powder and iron powder by weight.

Compressive strength, split tensile strength and flexural strength were determined at 7 and 28 days. Test results showed that for $10 \%$ ratio of Granite powder in concrete, the increase in the compressive strength was about $30 \%$ compared to normal concrete. Similar results were also observed for the flexure.

From the literature review, it can be observed that much research work has been carried out on concrete replacing river sand by granite powder and manufactured materials like cooper slag, fly ash, iron powder etc., experiments has been conducted on the mechanical properties of concrete for various percentage replacement of fine aggregate by granite powder and manufactured waste. But little information is available on concrete with the crushed stone like gneiss dust. Their role on the mechanical properties of concrete is still not totally investigated.

This paper reports the result of a research undertaken to investigate the influence of the mixture of quarry gneiss on compressive strength of concrete.

*Corresponding author: Luc Leroy MN, Laboratory of Material Sciences, Department of Physics, Faculty of Sciences, University of Yaoundé 1, PO BOX 812 Yaoundé, Cameroon, Tel: +237697419489; E-mail: mamboulucleroy@gmail.com

Received August 01, 2017; Accepted October 03, 2017; Published October 07, 2017

Citation: Luc Leroy MN, Guy Molay TG, Joseph N, Jean-Marie Bienvenu N (2017) Analysis of Strength Hydraulic Concrete Produced with a Mixture of Crushed Gneiss and Alluvial Sand. J Appl Mech Eng 6: 289. doi: 10.4172/2168-9873.1000289

Copyright: ( 2017 Luc Leroy MN, et al. This is an open-access article distributed under the terms of the Creative Commons Attribution License, which permits unrestricted use, distribution, and reproduction in any medium, provided the original author and source are credited. 


\section{Materials and Methods}

\section{Materials}

The materials used for making concrete are Cement, water, coarse aggregate, alluvial sand and crushed gneiss as fine aggregate.

Cement: Concrete is a three-phase composite material consisting of a cementation matrix, a solid phase and a cement paste interface. The cement paste ensures a bond between the various constituents. In civil engineering, the most commonly used cement is Portland cement. For various reasons (economic, environmental, technical), cement plants use mineral and organic additives. Thus, there exist in commerce, a multitude of cement with technical names that are functions both of the nature of the adjuvant and the quantity of clinker. To achieve the objective of this work, Portland cement composed of CPJ-CEM II / A 42.5 was chosen.

It is produced by the DANGOTÉ Cement factory and marketed in Cameroon. The various tests relating to the determination of its physical and mechanical properties were carried out at the National Laboratory of Civil Engineering of Cameroon (LABOGENIE) and the various results are shown in Table 1 below.

Sand : Sand is an inert and essential component for concrete. It ensures the continuity between the cement paste and the aggregates by filling the existing voids. For the construction of traditional concretes, construction engineering has always used alluvial sand. However, recently industrial companies produce quarry sands which could constitute an alternative to river sands. In order to investigate their use as sand for concrete, we had carried out a certain number of identification tests. Two sands of different origins and nature were selected; one of alluvial nature from the Sanaga River (SS) which is the longest river in Cameroon and the other of metamorphic origin (SG) from the industrial quarry of the company Razel located in the locality of Nkometou. Table 2 below summarizes the results of identification carried out on these different sands.

Coarse aggregates: Aggregates are the inert components of concrete. They constitute the concrete skeleton. They occupy $60 \%$ to $75 \%$ of the volume of the concrete. Their size, shape and granulometry play an important role in obtaining the properties of concrete.

In order to carry out this work, we selected granular fractions 5/15 and 5/25 from gneiss valorized by the industrial quarry of Razel located in Nkometou. The results of the tests carried out on these aggregates are contained in Table 3 .

Water for mixed: The water used for the different mixed concrete comes from Cameroon's water (CDE). The water is supposed to be potable and contains no harmful impurities. It is therefore very useful for making concrete.

\section{Experimental method}

The experimental program consisted of making cylindrical samples of concrete. These samples of concrete are constituted of different sands, same gravels, same cement and same water. The measurements are made on fresh and hardened concretes. Sagging is the only measure performed on fresh concrete. Concerning the hardened concrete, we submitted to compressive test at 7,28 and 90 days in order to determine the uni-axial compressive strength. Each value of the compressive strengths obtained is the average of three values resulting from testing of three samples. In short, 75 samples were made and clogged.

\section{Details of mixed concrete}

The present experiment is carried out to investigate strength properties of mixed concrete in which Fine aggregate (river sand)

\begin{tabular}{|c|c|c|c|c|c|c|c|c|c|}
\hline \multicolumn{6}{|c|}{ Physical Characteristics } & \multirow{2}{*}{\multicolumn{4}{|c|}{ Mechanical Characteristics }} \\
\hline Apparent density $\left(\mathrm{t} / \mathrm{m}^{3}\right)$ & Consistency (\%) & $\begin{array}{c}\text { Specific density } \\
\left(\mathrm{t} / \mathrm{m}^{3}\right)\end{array}$ & $\begin{array}{c}\text { Specific surface } \\
\left(\mathrm{cm}^{2} / \mathrm{g}\right)\end{array}$ & Expa & $(\mathrm{mm})$ & & & & \\
\hline \multirow{3}{*}{0.95} & \multirow{3}{*}{29} & \multirow{3}{*}{3.14} & \multirow{3}{*}{3425} & Cold & Heat & Days & 2 & 7 & 28 \\
\hline & & & & \multirow{2}{*}{2} & \multirow{2}{*}{2} & Compressive Strength (Mpa) & 25 & 35 & 45 \\
\hline & & & & & & Split Tensile Strength (Mpa) & 7 & 10 & 13 \\
\hline
\end{tabular}

Table 1: The different properties of cement.

\begin{tabular}{|c|c|c|c|}
\hline Types of sand & Apparent density $\mathbf{( g / \mathbf { m } ^ { \mathbf { 3 } } )}$ & Specific Density $\mathbf{( g / \mathbf { m } ^ { \mathbf { 3 } } )}$ & Fineness Modulus \\
\hline SS (alluvial) & 1.39 & 2.62 & 2.72 \\
\hline SG (gneiss) & 1.8 & 2.87 & 2.87 \\
\hline $75 \%$ SS + $5 \%$ SG & 1.47 & 2.67 & 73.20 \\
\hline $50 \%$ SS $+50 \%$ SC & 1.56 & 2.74 & 2.77 \\
\hline $25 \%$ SS $+75 \%$ SC & 1.68 & 2.81 & 3.06 \\
\hline
\end{tabular}

Table 2: Physical characteristics of sands.

\begin{tabular}{|c|c|c|c|c|c|}
\hline Coarse aggregates & CA (\%) & Apparent density $\left(\mathrm{g} / \mathrm{m}^{3}\right)$ & Specific Density $\left(\mathrm{g} / \mathrm{m}^{3}\right)$ & Los Angeles (\%) & Micro Deval (\%) \\
\hline Coarse $5 / 15$ & 36.43 & 1.50 & 2.8 & 18 & 4.26 \\
\hline Coarse $15 / 25$ & 25.10 & 1.63 & 2.8 & 14 & 5.50 \\
\hline
\end{tabular}

Table 3: Properties of coarse aggregate $5 / 15$ and 15/25.

\begin{tabular}{|c|c|c|c|}
\hline No & Designation of Mix & River sand (\%) & Replacement of sand with the crushed gneiss (\%) \\
\hline 1 & CN & 100 & 0 \\
\hline 2 & CG25 & 75 & 25 \\
\hline 3 & CG50 & 50 & 50 \\
\hline 4 & CG75 & 25 & 75 \\
\hline 5 & CG100 & 0 & 100 \\
\hline
\end{tabular}

Table 4: Mixed designation with mixture compositions. 
is to be fully replaced with crushed gneiss. The laboratory program conducted in this investigation focused on five basic mixing and the mixing were designated by the grade of concrete and the fine aggregate type used. Mixture incorporating $0 \%$ gneiss sand (100\% river sand), $25 \%$ gneiss sand ( $75 \%$ river sand), $50 \%$ gneiss sand (50\% river sand), $75 \%$ gneiss sand $(25 \%$ river sand) and $100 \%$ gneiss sand $(0 \%$ river sand), were designed as CB0, CB35, CB50, CB65, CB100 respectively. The resultant mixture compositions are shown in the Table 4.

\section{Method}

\section{Pétrographic properties}

The observations of the thin section of massive rocks of gneiss permit us to know the names, shapes and various minerals that contain these sands (Figures 1 and 2).

Formulation (composition study): The methodology for the formulation of concrete is the Dreux-Gorisse method [10]. We choose to make concretes with the characteristics contained in Table 5 .

Compressive strength of hardened concrete : Compressive strength test is the most common test conducted on concrete, because it is easy to perform and most of the desirable characteristic properties of concrete are quantitatively related to its compressive strength. The simple compressive strength of the concrete was determined on $12 \times$

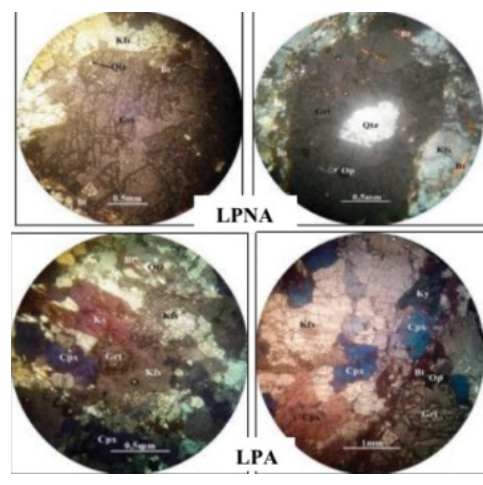

Figure 1: Microscopic aspect of gneiss.

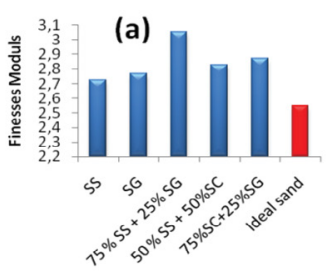

Types of sands

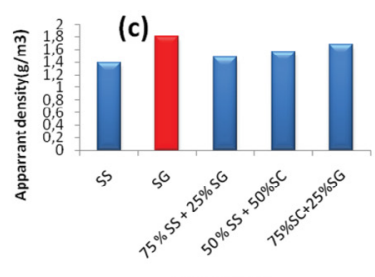

Types of sands

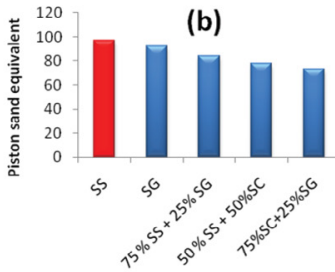

Types of sands

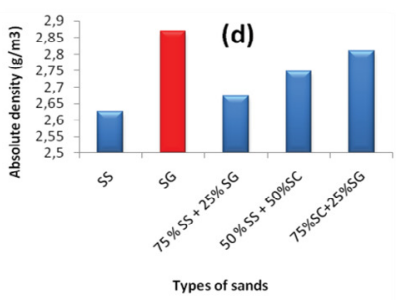

Figure 2: Compressive strength of concrete as function of mixture of sand: a) At 7 days, b) At 14 days, c) at 28 days, d) 7, 14, 28 days and compressive strength of different concrete as function of age.

\begin{tabular}{|c|c|c|c|c|c|}
\hline Designation of Mix & CN & CG25 & CG50 & CG75 & CG100 \\
\hline Cement $(\mathrm{Kg})$ & 375 & 375 & 375 & 375 & 375 \\
\hline Water $(\mathrm{L})$ & 229 & 229 & 229 & 229 & 229 \\
\hline Coarse 5/15 $(\mathrm{Kg})$ & 250.14 & 194.94 & 184.55 & 183.02 & 172.85 \\
\hline Coarse 15/25 $(\mathrm{Kg})$ & 863.53 & 856.49 & 849.46 & 842.43 & 835.40 \\
\hline Alluvial sand $(\mathrm{kg})$ & 612.7 & 479.77 & 325.15 & 163.19 & 0 \\
\hline E/C & 0.61 & 0.61 & 0.61 & 0.61 & 0.61 \\
\hline Gneiss sand $(\mathrm{kg})$ & 0 & 174.78 & 355.36 & 535.08 & 716.01 \\
\hline
\end{tabular}

Table 5: Compositions of the different concretes tested (for one cubic meter).

\begin{tabular}{|c|c|c|c|c|c|c|}
\hline \multirow{2}{*}{$\begin{array}{c}\text { Mix } \\
\text { Designation }\end{array}$} & \multicolumn{4}{|c|}{ Compressive strength (Mpa) } & \multicolumn{3}{|c|}{$\begin{array}{c}\text { Compressive strength } \\
\text { ratio }\end{array}$} \\
\cline { 2 - 7 } & 7 days & 28 days & 90days & 7 days & 28 days & 90 days \\
\hline CN & 27.08 & 32.52 & 37.07 & 1.00 & 1.00 & 1.00 \\
\hline CG25 & 25.27 & 30.44 & 35.69 & 0.93 & 0.94 & 0.96 \\
\hline CG50 & 24.86 & 27.53 & 31.38 & 0.92 & 0.85 & 0.85 \\
\hline CG75 & 28.95 & 31.31 & 35.69 & 1.07 & 0.96 & 0.96 \\
\hline CG100 & 17.12 & 24.84 & 28.32 & 0.63 & 0.76 & 0.76 \\
\hline
\end{tabular}

Table 6: Compressive strength of various concrete with replacement of alluvial sand by crushed gneiss sand at different ages and compressive strength ratio of various concrete.

$16 \mathrm{~cm}$ cylindrical specimens. The test is carried out according to the standard [11]. The specimens are loaded to failure in a compression testing machine conforming to the standard [12]. The maximum load reached is recorded and the compressive strength is obtained by the following equation:

$$
\sigma_{c}=\frac{F}{\pi r^{2}}
$$

Where $F$ the charge applied, $\sigma_{c}$ the compressive strength and $r$ the radius of specimen

\section{Results and Discussion}

In order to achieve the objective of this work, various laboratory tests were conducted on fine aggregate (alluvial sand and gneiss sand) and coarse aggregate (gneiss) to ascertain the suitability of using the aggregates for construction work.

Tests conducted include sieve petrographic and geotechnical analyzes. The concrete derived from them were tested in their fresh and hardened states. Below are presentation of data and details of the results obtained.

\section{Analysis of results}

This work focuses on the experimental study of using the crushed gneiss as partial and total replacement of alluvial sand in the production of concrete and comparing the results (compressive strength) to that obtained from conventional concrete made with alluvial sand.

Analyzes of the thin section of sand from rock was carried out at the Institute of Geological and Mining Research of Cameroon (IRGM) (Table 6).

These studies revealed that: SG sand originating from the crushing of gneiss is composed of garnet (10\% to $15 \%)$, quartz (10\% to $15 \%)$, biotite ( $15 \%$ to $20 \%$ ), disthene (5\%), alkaline feldspar (30\% to $40 \%)$ and clinopyroxene (8\%).

Moreover, the macroscopic observation of alluvial sand shows that it consists of more than $90 \%$ of quartz and micas in a very small proportion (about $5 \%$ ). It is a terrigenous sedimentary rock belonging to the arenite family and to the sub-family of unconsolidated arenites. 
Examination of Figure 2a shows that alluvial sand is preferential for the formulation of common concretes, due to its modulus of fineness ranging between 2.2 and $2.8[13,14]$.

The gneiss sand has a modulus of fineness above 2.8 and can therefore be referred to as coarse sand. A correction by the Abrams method could reduce the Fineness Modulus in the range of 2.2 to 2.8 .

Figure $2 \mathrm{~b}$ shows that the gneiss sand is the densest sand. This is explained by the fact that this sand is composed of a set of minerals with densities greater than quartz mineral. The density of mixed sand increases with the proportion of mixtures. The smallest value of the density is that obtained the alluvial sand. This is justified by its high content of quartz mineral.

Figure $2 \mathrm{c}$ shows that the apparent density value of quarry sand is higher than that of alluvial sand. This is due to the fact that gneiss sand contains high quantity of fines and the irregular forms of aggregate. These elements fill the voids left by coarse fraction. Moreover, the apparent densities of the mixed sands increase with the proportion of

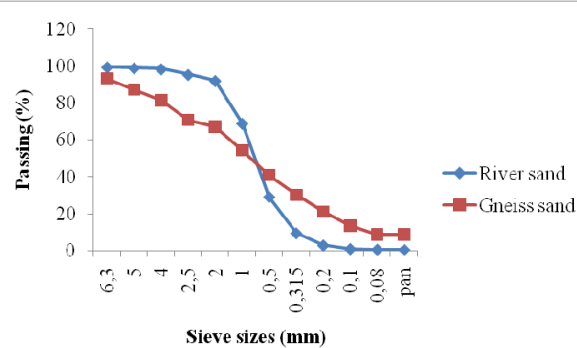

Figure 3: Sieves analysis of fines aggregates (alluvial and Gneiss sand).
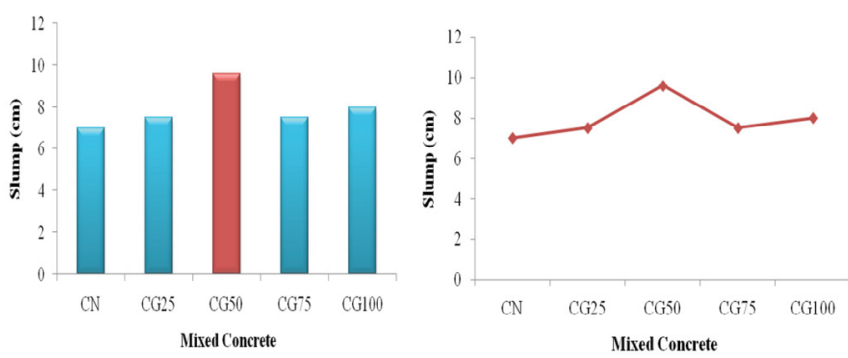

Figure 4: Workability of fresh concrete.
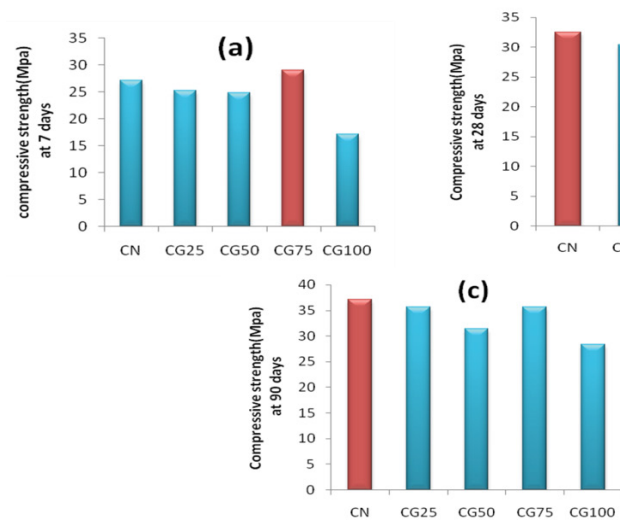

Figure 5: Compressive strength of concrete as function of mixture of sand: a) at 7 days, b) at 28 days, c) at 90 days.

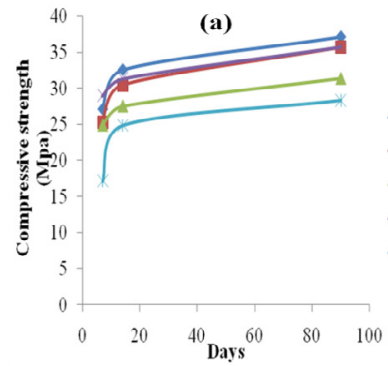

(b)

Figure 6: a) Compressive strength of different concrete as function of days, b) Compressive strength of $\mathrm{CN}$ and CG75 as function of days.

quarry sands. This could be attributed to irregular shapes of grains and the proportions of fines in the mixture.

The analysis of Figure $2 \mathrm{~d}$ shows an almost total absence of clay minerals in all the sands used and their corresponding mixtures. We can qualify all the mixed sands as clean sands with low percentage of clay minerals. These sands are perfectly suitable for making concrete. Gneiss sand has the lowest value of Piston Sand Equivalent (ESP= 73.2). However alluvial sand, with a Piston sand equivalent of 97.1, is very clean sand, characterized by almost a complete absence of fine clay which can cause a defect of plasticity of concrete that will be corrected by adding an adjuvant.

According to Figure 3, the granulometric curves of alluvial sand are tight while those made on gneiss quarry sands are semi-spread. These two elements have an influence on the compactness of the mixture.

In Figure 4, the analysis of concretes made from different sands in their fresh and hardened state shows that a concrete made with $100 \%$ of alluvial sand is more malleable than those made by mixed sand. This can be justified by the rounded shape of grains observed in river sand.

Moreover, the greatest value of the subsidence is obtained for concrete CG50.

The results of the compressive strengths (Figures $5 a, 5 b$ and $5 c$ ) carried out on the various concretes show that concretes made from alluvial sand have the highest compressive strength values for all age. This can be explained by the better geotechnical properties favorable to alluvial sand than the quarry sand which contents relatively the high proportion of fines. Moreover, for the GC75 concrete, results for compressive strength are appreciable. This value is close to that obtained with alluvial sand. Thus, in the basic formulation, river sand can be substituted by proportions of $25 \%$ SS and $75 \%$ SG.

Figure 6 shows that at 7 days, the maximum value of compressive strength is obtained for CG75 concrete and for other days (28 and 90), the maximal values of compressive strength are obtained for conventional concrete $\mathrm{CN}$, followed by CG75 concrete.

\section{Conclusion}

Based on the experimental study undertaken the following conclusions are drawn:

1. The density of mixed sand increases with the proportion of mixtures. The smallest value of the density is that obtained the alluvial sand.

2. All mixed sands present the good geotechnical properties.

3. Concrete made with $100 \%$ of alluvial sand is more malleable than those made by mixed sand. 
Citation: Luc Leroy MN, Guy Molay TG, Joseph N, Jean-Marie Bienvenu N (2017) Analysis of Strength Hydraulic Concrete Produced with a Mixture of Crushed Gneiss and Alluvial Sand. J Appl Mech Eng 6: 289. doi: 10.4172/2168-9873.1000289

Page 5 of 5

4. At 7 days, the maximum value of compressive strength is obtained for CG75 concrete and for other days (28 and 90), the maximal values of compressive strength are obtained for conventional concrete $\mathrm{CN}$, followed by CG75 concrete.

5. The strength to compression of CG75 concrete is near to conventional concrete. Then it will be the appropriate concrete for construction.

\section{References}

1. Abdullahi M (2012) Effect of aggregate type on compressive strength of concrete. Int J Civil and structural Eng 2: 791-799.

2. Zeghichi L, Benghazi $Z$, Baali $L$ (2014) The effect of the kind of sands and additions on the mechanical behaviour of SCC. Physic Procedia Elsevier pp. 485-492.

3. Wakchaure MR, Er Shaikh AP, Er Gite BE (2012) Effect of types of fine aggregate on mechanical properties of cement concrete. Int J Modern Eng Res 2: $3723-3726$.

4. Chiemela C, Walter IE, Ogedi IH, Peter OC, Mong O (2015) Comparing the compressive strengths of concrete made with river sand and quarry dust. IJRRAS 22: 31-38.

5. Sohail M, Wahab A, Khan MA (2013) A Study on the mechanical properties of concrete by replacing sand with waste foundry sand. Int J Emerging Technol and Advanced Eng 3: 83-87.

6. Suresh N, Manjunatha M (2016) Effect of different types of fine aggregates on mechanical properties of concrete - A review. The Indian Concrete J 69-71.

7. Félix Kala T (2013) Effect of granite powder on strength properties of concrete Int J Eng and Sci 2: 36-50.

8. Kayathri K, Kumar CV, Rani MG, Karthik K (2014) Effect of copper slag, fly ash and granite powder as a partial replacement in fine aggregate. Int $\mathrm{J}$ Innovative Res sci, Eng and Technol 3: 439-443.

9. Ghannam S, Najm H, Vasconez R (2016) Experimental study of concrete made with granite and iron powder as partial replacement of sand. Sustainable Materials and Technologies 9: 1-9.

10. Dreux G, Festa J (1998) New guide to concrete and its constituents. Eyrolle Edition, (8th edn), Paris, France.

11. European Standard NF EN 12350-2 (1999) Test for fresh concrete, Part 2 Sink test.

12. European Standard NF EN 12350-6 (1999) Test for fresh concrete, Part 6 : Density", AFNOR.

13. European Standard NF EN 12390-3 (2003) Test for hardened concrete, Part 3 Compressive strength of test specimens", AFNOR.

14. European standard NF EN 12390-4 (2000) Tests for hardened concrete, Part 4: Compressive strength - Characteristics of test machines. AFNOR. 